\title{
Chemical Analysis and Toxicological Assessment of Defatted Greenwayodendron Suave lens Seeds in Rat Feed
}

\author{
Ajayi I. A.*Aghanu V. N. and Adenuga T. B. \\ Industrial unit, Chemistry Department, Faculty of Science, University of Ibadan, Nigeria
}

\begin{abstract}
This study was carried out to compare the effect of total replacement of wheat with defatted Greenwayodendron suaveolens seeds (DGSS) which was used as an additive in compounding the feed for albino rats. The phytochemical characters of DGSS are alkaloids, phenols and reducing sugars. Mineral composition of DGSS showed that it is rich in potassium $(75100 \pm 0.37 \mathrm{mg} / \mathrm{kg})$, magnesium $(41900 \pm 0.08 \mathrm{mg} / \mathrm{kg})$ and calcium $(11700 \pm 0.04 \mathrm{mg} / \mathrm{kg})$. The proximate composition of DGSS indicated a high level of carbohydrate (55.84\%) and crude fibre (12.86\%). Proximate compositions of the compounded feed for group A, the control group (CFA) and compounded feed for group $B$, the experimental group (CFB) pointed out that there were significant differences in crude protein, crude fat and crude fibre contents of the compounded feeds. CFA and CFB were used to feed the rats for an experimental period of eight weeks. Weekly record of the body weight of the rats showed a gradual increase in body weight. Tissue pathology of the rat organs (liver, kidney, heart and spleen) compared closely in the two groups. Haematology and blood biochemistry analyses gave no significant differences in all the parameters for the two groups.
\end{abstract}

Key words: Greenwayodendron suaveolens seeds, rat feed, toxicological assessment, haematological analysis

\section{Introduction}

Seeds are important sources of edible oil. The sources include groundnut, cotton seed, sunflower, palm kernel, avocado and olive etc. These oils are usually extracted using different methods such as solvent extraction and expression. After the extraction, most residues known as seed cake (Secrest, 1994) are usually discarded with the exception of those from the more conventional seeds which are primarily used as food for livestock. Recently, attention has shifted to some non-conventional seeds and the usefulness of the defatted seeds. Some uses of defatted seeds that are in literature include their uses as inexpensive source of protein (Mariod et al., 2010) and as an adsorbent material (Adachi et al., 2001).

Greenwayodendron suaveolens, a plant from Annonaceae family, is restricted to tropical Africa and has been separated from Polyalthia suaveolens. It is regarded as one of the lost crops of Africa and is widespread from southern Nigeria to western Uganda, northern Tanzania, southern Democratic Republic of Congo and Cabinda (Angola). In West Africa, it is regarded as one of the useful crops. Some of the common names in Nigeria include; Edo (ewai), Isekiri (eleku), Urhobo (osharo) and Yoruba (agudugbu) (Keay, 1989). Greenwayodendron suaveolens is a deciduous, medium-sized to fairly large tree up to $35-45 \mathrm{~m}$ tall. The inner bark is fibrous and has a yellow to orange or pale brown colour; it becomes brownish or blackish upon exposure, with a strong resinous smell. Different parts of this plant have numerous uses. The wood is used for house construction, joinery, mine props, furniture and stakes for yam cultivation, rafters and shafts of spears. It is suitable for flooring, interior trim, railway sleepers, toys, novelties, agricultural implements, vats, draining boards, food containers, turnery, veneer and plywood.

Root, leaves and barks of this plant are used in traditional medicine for the treatment of fever, rheumatism pains, oedema, swollen glands, headache, stomach ache, constipation, hernia, facilitation of child birth, fertility and as ornamentals, anthelmintic and aphrodisiac (Bele et al., 2011 and Tafokou, 2011). In Cameroon and Gabon, the bark is applied to scarifications for the treatment of malaria. In Democratic Republic of Congo, pounded bark is used in a mixture with other plants to make arrow poison while in Nigeria, the leaf has been recorded being taken internally for menorrhagia; the fruit is equally edible (Burkill, 1985).

This research is based on the chemical analysis and short-term toxicological evaluation of defatted Greenwayodendron suaveolens seeds as an additive in rat feed.

Plant Material

\section{Materials and Methods}

Greenwayodendron suaveolens seeds were picked from the Botanical Garden, University of Ibadan, Ibadan in Oyo State, Nigeria. The thin layers covering the seeds were manually decorticated to remove the kernels. 


\section{Sample preparation}

The kernels of Greenwayodendron suaveolens were ground using a domestic blender to give the coarse seed flour which was subjected to solvent extraction with a soxhlet extractor using normal hexane $\left(68^{\circ} \mathrm{C}\right)$ as the solvent. The seed oil obtained, after distilling off the hexane, was stored in a labeled flask. The defatted seed was dried, further reduced to a fine powder and stored at room temperature.

Proximate analysis of defatted seed and compounded feed

Moisture, crude fat, crude protein, ash and crude fibre contents of the defatted seeds and the compounded feeds were analyzed using the method of AOAC (1990). Carbohydrate content was determined by difference $[100$ - (crude protein + crude fat + ash + crude fibre) $]$.

Analysis of mineral elements of defatted seeds

Mineral composition of DGSS was determined following the method used by Ajayi et al., (2006) and Idouraine et al., 1996). One gram of the seeds was ashed in a muffle furnace at $550{ }^{\circ} \mathrm{C}$ for 5 hours until a white ash was obtained. The minerals were extracted from ash by adding $3 \mathrm{ml}$ of concentrated $\mathrm{HNO}_{3}(63 \%)$. The digest was carefully filtered into $100 \mathrm{ml}$ standard bottle and made up to mark with deionized water. All the minerals were estimated with the use of an atomic absorption spectrophotometer (Perkin Elmer model 703, USA) with the exception of sodium which was determined by flame photometric method. The instrument was calibrated with standard solutions containing known amounts of the minerals determined.

\section{Phytochemical screening}

DGSS was subjected to phytochemical screening for the identification of carbohydrates (Molisch test), reducing sugars (Fehling's test), alkaloids (Dragendorff's, Mayer's, and Wagners's tests), glycosides (hydrolysis test), flavonoids (ammonia and aluminium chloride tests), saponins (using frothing and emulsion), tannins (ferric chloride and lead acetate tests) and steroids and terpenoids following the methods of Ajayi et al. (2011) and Harbone (1984).

\section{Feed compounding}

Two feeds (control and experimental), averaging 100\%, were formulated for young albino rats. The diets were prepared according to the procedure described by Souza et al. (2007) with slight modification. Feed formulation and proximate composition of DGSS and the diets are shown in Tables 1 and 2 respectively. The following were used to compound the feed: maize (40\%), soybean (18\%), bone (3\%), salt $(0.1 \%)$, groundnut cake (14\%), corn bran (10\%), wheat $(0.45 \%)$, oyster shell $(0.25 \%)$ and palm kernel cake $(0.7 \%)$. Wheat was replaced with $0.45 \%$ of DGSS in the experimental diet. $0.45 \%$ of wheat was incorporated in the control diet because only $0.45 \%$ of DGSS was introduced in the experimental diet. Pelleting of each diet was carried out by passing the blended mixture through a pellet machine. The pellets were sun dried for two days and packed in two separate transparent plastic buckets.

\section{Animal, diets and feeding}

Fourteen wistar rats of about eight weeks old weighing between $100 \mathrm{~g}-125 \mathrm{~g}$ were bought from the Animal house, Veterinary Extension Unit, University of Ibadan, Nigeria. The rats were grouped according to their body weight into 2 groups of A and B for control and experimental groups respectively. The rats were housed in perforated plastic cages during the eight weeks of this study and had access to feed and water $a d$ libitum. Their feed intake was monitored daily while their body weight was noted weekly (Leontowicz et al., 2007).

\section{Haematology and biochemistry of rat blood}

Haematological analyses were carried out in about $3 \mathrm{ml}$ of rat blood collected into EDTA bottles through ocular puncture. The packed cell volume $(\mathrm{PCV})$, haemoglobin $(\mathrm{Hb})$ concentration, red blood cell (RBC), white blood cell (WBC), differential WBC counts, mean corpuscular volume (MCV) and mean corpuscular haemoglobin concentration $(\mathrm{MCHC})$ were determined and calculated respectively using standard procedures and technique as described in Ministry of Agriculture and Food manual of Veterinary investigation (MAFF, 1984). Albumin and globulin were determined by colorimetry. The albumin/globulin ratio was obtained by dividing the calculated albumin value by the calculated globulin value. Aspartate aminotransferase (AST) and alanine aminotransferase (ALT) were also determined (MAFF, 1984).

\section{Tissue pathology}

Rats were sacrificed for histopathological analyses of the heart, liver, kidney and spleen. Small portions of these tissues already stored in formalin were fixed and put through series of dehydration in graded concentration of xylene. They were embedded in wax, sectioned at $5 \mu$ and transferred to clean glass slides. The 
thin sections were stained with haemotoxylin and eosin ( $\mathrm{H}$ and $\mathrm{E})$ dyes for examination under the light microscope for histological changes (Ajayi et al., 2008; Jain, 1986).

\section{Statistical analysis}

Differences between groups were determined by 2 -tailed t-test for equality of means at $95 \%$ confidence interval of the difference. Values of $<0.05$ were considered significant.

\section{Results and Discussion}

\section{Proximate analysis of the defatted seed and compounded feed}

Proximate composition of DGSS as presented in Table 2 showed low protein content (8.64\%). It is lower than the protein content of fenugreek seed meal (29.11\%), soybean meal (44.03\%), wheat bran (14.98\%) and even cornmeal (9.55\%) as reported by Ahmed et al. (2009). It could be seen as rich in crude fibre $(12.86 \%)$ and carbohydrate $(55.84 \%)$. This is an indication that DGSS is a good source of roughage in animal feeds. The ash content is quite low while the moisture is high. After compounding the feed, samples were analyzed to ascertain their proximate composition. There was an increase in the crude protein, ash and carbohydrate contents of the compounded feeds when compared to the defatted seed (Table 2). Also, crude fat, crude fibre and moisture contents decreased in the compounded feed. Interestingly, moisture, ash and crude fat contents were not significantly different in both feeds labeled CFA and CFB but crude protein, crude fat and crude fibre contents differed significantly in the two feeds. The crude fibre content $(5.59 \pm 0.024 \%$ for CFA and $5.93 \pm 0.02 \%$ for $\mathrm{CFB}$ ) and carbohydrate value of around 58\% suggests that DGSS could be useful as supplement in compounding animal feed.

\section{Mineral elements}

Mineral element content of DGSS is presented in Table 3. DGSS is rich in potassium, magnesium and calcium. Potassium $(75100 \pm 0.37 \mathrm{mg} / \mathrm{kg})$ had the highest value followed by magnesium $(41900 \pm 0.08 \mathrm{mg} / \mathrm{kg})$. All the minerals present in DGSS are higher in quantity when compared to those reported for African oil bean seeds (Enujiugha and Akanbi, 2005). Magnesium is nothing short of a miracle mineral in its healing effect on a wide range of diseases as well as in its ability to rejuvenate the aging body, maintain healthy bones alongside calcium, may reverse osteoporosis, prevents cardiovascular diseases, regulates high blood pressure, treats diabetes, migraines, insomnia and depression (Newsmax, 2011). Other elements present in DGSS are zinc $(1000 \pm 0.01 \mathrm{mg} / \mathrm{kg})$, calcium $(11700 \pm 0.04 \mathrm{mg} / \mathrm{kg})$, sodium $(2010 \pm 0.00 \mathrm{mg} / \mathrm{kg})$ and iron $(2120 \pm 0.00 \mathrm{mg} / \mathrm{kg})$.

\section{Phytochemical analysis of G. suaveolens}

The phytochemical properties of DGSS were screened and the result showed that it contains alkaloids, phenols and reducing sugars (Table 4). These phytochemicals exhibit diverse pharmacological and biochemical actions when ingested by animals. Alkaloids are known to show medicinal activity as well as physiological activity (Sofowora, 1993).

\section{Feed intake and body weight changes}

Feed consumption and resultant change in body weight of test and control rats are shown in Table 5 . There was a gradual increase in the quantity of feed consumed by rats in the two groups throughout the feeding trial that lasted for eight weeks. It was observed that there was no significant difference in the quantity of the experimental feed as well as the control feed consumed by the rats with the exception of the second week alone. There was steady but not rapid increment in the body weight of the rats during the experimental period. Significant differences were noted within the groups for body weights of rats during weeks zero and one. For week eight, there was no significant difference in the body weight of rats $(\mathrm{P}<0.05)$ in the two groups.

\section{Organ weights}

There was no significant difference in the weight of the liver, kidney, heart and spleen of the control and experimental rats (Table 6). Liver weight was from 6.84 $\pm 1.08 \mathrm{~g}$ (control group) to $6.17 \pm 1.15$ (experimental group). $12.8 \pm 0.60 \mathrm{~g}$ to $16.0 \pm 0.98 \mathrm{~g}$ has been previously reported as liver weights for rats fed with Vicia faba, canola, soybean, virgin olive and sesame oils (Marcarulla et al., 2001 and Baba et al., 2000). The body weight of the rats used in this study differed only at the initial week and the next in the two groups. Therefore, it formed the bases of the trend followed by the organ weights. The spleen of the rats in this study $0.69 \pm 0.13 \mathrm{~g}$ (control group) and $0.87 \pm 0.16 \mathrm{~g}$ (experimental group) compares closely with $0.73 \pm 0.03 \mathrm{~g}$ to $0.86 \pm 0.10 \mathrm{~g}$ reported by Topping et al. (2012) for spleen of rats in six different groups fed with different sources of starch in a Western diet moderate in fat and protein.

\section{Haematological and biochemical parameters}


The data in Table 7 reveals the response of haematological indices of the rats' blood. No significant difference $(\mathrm{P}>0.05)$ was recorded. The absence of significant differences as shown among the two groups for the haematological parameters is an indication that the defatted seeds may not be toxic. The haemoglobin and packed cell volume of the rats showed that the rats were not anaemic. Ajayi et al. (2004) gave similar report for rats fed with $T$. occidentalis oil. Diets compounded with DGSS had no adverse effect on the blood of the rats under study as it compared favourably with the indices obtained for the diet compounded with wheat. The haematological values from this study are similar to what Vishnu et al., (2010) reported in the toxicity study of Garcinia mangostana pericarp extract in rats. All serum biochemical parameters did not differ significantly from each other. Alanine aminotransferases enzyme activity examined was high $(20.33 \pm 9.87)$ in the case of the experimental feed as against $15.14 \pm 6.41$ obtained for the control group.

\section{Histopathology}

Histopathology result revealed no major complications in the tissues of all the rats in the two groups. For the test rats, coronary vessels were markedly congested with increased cellularity in the inter-myocardial tissue (Figure 1). Spleen of test rats had no visible lesions; there were normal discrete splenic follicles with germinal centers.

\section{Conclusion}

Deffated Greenwayodendron suaveolens seeds could be a good source of roughage and fibre in feed for livestock. Though it has a low protein content, it is not a limitation since cheap sources of protein are readily available in groundnut cake and other protein residues. DGSS is also rich in magnesium and calcium that are essential minerals in nutrition. It could even be medicinal because of the presence of alkaloids detected during its phytochemical screening. There was no significant difference between the tissues and body weight gain of the control and test rats. There were no significant differences in the haematological and biochemical parameters in the blood of the control and test rats. The defatted seeds could possibly be integrated in formulating rat feed.

\section{Acknowledgement}

The authors wish to acknowledge the Department of Chemistry, Faculty of Science and Veterinary Pathology Department, Faculty of Veterinary, University of Ibadan, Ibadan, Nigeria for making their facilities available for this study.

\section{References}

[1]. Adachi, A., Komiyama, T., Tanaka, T., Nakatani, M., Muguruma, R. and Okano, T. 2001. Removal efficiency of defatted seed for organochlorine compounds. Journal of Health Science 47: 54-59.

[2]. Ahmed, A. M. M., Mohammad, H. A., Amani, M. and Asmaa, S. 2009. Effect of using dried fenugreek seeds as natural feed additives on growth performance, feed utilization, whole-body composition and entropathogenic Aeromonas hydrophila-challinge of monsex nile tilapia O. niloticus (L) fingerlings. Australian Journal of Basic and Applied Sciences 3: 1234-1245. Ajayi, I. A., Oderinde R. A., Taiwo V. O. and Agbedana, E. O. 2004. Dietary effects on plasma lipid and tissues of rats fed with nonconventional oil of Telfairia occidentalis. Journal of

[3]. Science Food and Agriculture 84: 1715-1721.

[4]. Ajayi, I. A., Oderinde, R. A., Kajogbola, D. O. and Uponi J. I. 2006. Oil content and fatty acid composition of some underutilized legumes from Nigeria. Food Chemistry 99: 115-120.

[5]. Ajayi, I. A., Oderinde, R. A., Taiwo, V. O. and Agbedana, E.O. 2008. Short-term toxicological evaluation of Terminalia catappa, Pentaclethra macrophylla and Calophyllum inophyllum seed oils in rats. Food Chemistry 106: 458-465.

[6]. Ajayi, I. A., Ajibade, O. and Oderinde, R. A. 2011. Preliminary phytochemical analysis of some plant seeds. Research Journal of Chemical Sciences 1: 58-62.

[7]. AOAC. 1990. Official Methods of Analysis, 15th ed. Association of Official Analytical Chemists, Arlington, VA

[8]. Baba, N. H., Ghossoub, Z. and Habbal, Z. 2000. Differential effects of dietary oils on plasma lipids, lipid peroxidation and adipose tissue lipoprotein lipase activity in rats. Nutrition Research 20: 1113-1123.

[9]. Bamishaiye, E. I., Muhammad, O. I. and Bamishaiye, O. M. 2010a. Haematological parameters of albino rats fed on tiger nuts (Cyperus esculentus) tuber oil meal-based diet. The Internet Journal of Nutrition and Wellness 10 (1).

[10]. Bele, M. Y., Focho, D. A., Egbe, E. A. and Chuyong, B. G. 2011. Ethnobotanical survey of the uses of Annonaceae around mount Cameroon. African Journal of Plant Science 5: 237-247.

[11]. Burkill, H. M. 1985. The useful plants of West Tropical Africa. 2nd Edition 1, Families A-D. Royal Botanic Gardens, Kew, Richmond, United Kingdom. p 960.

[12]. Enujiugha, V. N. and Akanbi, C. T. 2005. Compositional changes of African oil bean (Pentaclethra macrophylla) seed during thermal processing. Pakistan Journal of Nutrition 4: 27-31.

[13]. Harbone, J. B. 1984. Phytochemical Methods: a guide to modern techniques of plant analysis. $2^{\text {nd }}$ edition. London: Chapman and Hall.

[14]. Idouraine, A., Kohlhepp, E. A., Weber, C. W. 1996. Nutrient constituents from eight lines of naked seed squash. Journal of Agricultural Food Chemistry 44: 721-724.

[15]. Jain, N. L. 1986. Schalmes Veterinary Haematology. Volume III, $4^{\text {th }}$ Edition, Lea and Ferbiger, Philadelphia. pp. 281.

[16]. Keay, R. W. J. 1989. The Trees of Nigeria, New York: Oxford University Press Oxford. 
[17]. Leontowicz, H., Leontowicz, M., Drzewiecki, J., Jastrzebski, Z., Haruenkit, R., Poovarodom, S., Park, Y. S., Jung, S. T., Kang, S. G., Trakhtenberg, S., Gorinstein, S. 2007. Two exotic fruits positively affect rat's plasma composition. Food Chemistry 102: 192200.

[18]. Macarulla, M. T., Medina, C., Aranzazu De Dieg, M., Zulet, A., Martinez, J. A., Noel-Sberville, C., Higueret, P. and Portillo, M. P. 2001. Effects of the whole seed a protein isolate of faba bean (Vicia faba) on the cholesterol metabolism of hypercholesterolaemic rats. British Journal of Nutrition 85: 607-614.

[19]. MAFF (1984), Ministry of Agriculture and Food Manual of Veterinary investigation. Laboratory Techniques. Volume 2. Reference Book 390. Third edition.

[20]. Mariod, A. A., Fathy, S. F. and Ismail, M. 2010. Preparation and characterization of protein concentrates from defatted kenaf seed. Food Chemistry 123: 747-752.

[21]. Newsmax 2011. Top 5 Health Benefits of Magnesium. Thursday, 20 Jan 2011 03:13 PM NEWSMAX.COM America's News Page (C) 2012 Newsmax Media, Inc.

[22]. Secrest, R. 1994. "Cooking Oil". How Products are Made. http://www.encyclopedia.com/doc/1G2-2896500043.html. Retrieved 2008-06-17.

[23]. Sofowora, A. 1979. Medicinal plants and traditional medicine in Africa. Spectrum books Ltd. Ibadan, Nigeria, p. 289.

[24]. Souza, A. R. de., Martins, L. P., Faira, L. C. de., Martins, M. E. P., Fereira, R. N., Silva, A. M. L. da., Gil, E. S., Conceição, E. C. da. 2007. Studies on the bioavailability of zinc in rats supplemented with two different zinc-methionie compounds. Latin American Journal of Pharmacy 26: 825-830.

[25]. Topping, D. L., Conlon, M. A., Kerr, C. A., McSweeney, C. S., Dunne, R. A., Shaw, J. M., Kang, S., Bird, A. R., Morell, M. K., Lockett, T. J., Molloy, P. L., Ahmed R., Toden, S. and Clarke, J. M. 2012. Resistant starches protect against colonic DNA damage and alter microbiota and gene expression in rats fed a Western diet. Journal of Nutrition First published ahead of print March 28 , 2012 as doi:10.3945/jn.111.147660.

[26]. Tafokou, R. B., 2011. Greenwayodendron suaveolens (Engl. \& Diels) Verdc. In: Lemmens, R.H.M.J., Louppe, D. and OtengAmoako, A.A. (Editors). Prota 7(2): Timbers/Bois d'œuvre 2. [CD-Rom]. PROTA, Wageningen, Netherlands.

[27]. Vishnu, P. V., Sankari, G., Mallika, J., Surapaneni, K. M., Aishwarya, T. S., Saraswathi, P., Chandra, S. and Gopan, V. S. 2010. Auto fluorescence and fourier transform - infra red (FTIR) spectral investigation on di ethyl nitrosamine (Den) induced hepatocellular carcinoma, treated with pericarp extract of Garcinia mangostana Linn. in rats. Journal of Clinical and Diagnostic Research 4: 3289-3297.

Table 1. Percentage composition of the feeds

\begin{tabular}{|l|l|}
\hline Ingredients & Composition (\%) \\
\hline Maize & 40.00 \\
\hline Soy bean & 18.00 \\
\hline Bone & 3.00 \\
\hline Salt & 1.00 \\
\hline Groundnut cake & 14.00 \\
\hline Palm kernel cake & 7.00 \\
\hline Corn bran & 10.00 \\
\hline Wheat/DGSS & 4.50 \\
\hline Oyster shell & 2.50 \\
\hline
\end{tabular}

Table 2. Proximate analysis of DGSS and compounded feeds

\begin{tabular}{|l|l|l|r|}
\hline Parameters (\%) & DGSS* & \multicolumn{2}{|l|}{ Compounded feeds } \\
\cline { 3 - 4 } & & CFA & CFB \\
\hline Crude protein & 8.64 & $16.68 \pm 0.10^{\mathrm{s}}$ & $16.25 \pm 0.13^{\mathrm{t}}$ \\
\hline Crude fat & 4.19 & $3.65 \pm 0.02^{\mathrm{s}}$ & $\begin{array}{c}3.59 \\
\pm 0.02^{\mathrm{t}}\end{array}$ \\
\hline Crude fibre & & & $5.93 \pm 0.02^{\mathrm{t}}$ \\
\hline Ash & 12.86 & $5.59 \pm 0.04^{\mathrm{s}}$ & $6.26 \pm 0.08^{\mathrm{t}}$ \\
\hline Moisture & 0.03 & $6.35 \pm 0.03^{\mathrm{t}}$ & $9.27 \pm 0.02^{\mathrm{t}}$ \\
\hline Carbohydrate & 18.44 & $9.30 \pm 0.05^{\mathrm{t}}$ & $5.69 \pm 0.22^{\mathrm{t}}$ \\
\hline
\end{tabular}

Mean \pm SD for three replicate analyses. Means in the same row having different

Letters are significantly different from each other (t-test) at 5\% level. * Single analysis. 
Table 3. Mineral composition of DGSS

\begin{tabular}{|l|c|}
\hline Minerals & Composition $(\mathrm{mg} / \mathrm{kg})$ \\
\hline Calcium & $11700 \pm 0.04$ \\
\hline Magnesium & $41900 \pm 0.08$ \\
\hline Potassium & $75100 \pm 0.37$ \\
\hline Sodium & $2010 \pm 0.00$ \\
\hline Manganese & $210 \pm 0.00$ \\
\hline Iron & $2120 \pm 0.00$ \\
\hline Copper & $3880 \pm 0.01$ \\
\hline Zinc & $1000 \pm 0.01$ \\
\hline
\end{tabular}

Mean \pm SD for three replicate analyses.

Table 4. Phytochemical analysis of DGSS

\begin{tabular}{|c|c|}
\hline Test & Inference \\
\hline Anthraquinones & - \\
\hline Alkaloids & + \\
\hline Cardiac glycosides & - \\
\hline Flavonoids & - \\
\hline Phenols & + \\
\hline Reducing sugar & + \\
\hline Steroids & - \\
\hline Tannins & - \\
\hline
\end{tabular}

+ Detected, - not detected

Table 5. Weekly feed consumption and body weight $(\mathrm{g})$ of rats from the control and experimental groups

\begin{tabular}{|l|l|l|l|l|}
\hline Week & Feed consumed & \multicolumn{3}{|l|}{ Body weight } \\
\hline & Control group & Experimental group & Control group & $\begin{array}{l}\text { Experimental } \\
\text { group }\end{array}$ \\
\hline 0 & & & $125.00 \pm 0.00^{\mathrm{s}}$ & $103.60 \pm 9.45^{\mathrm{t}}$ \\
\hline 1 & $130.00 \pm 6.07^{\mathrm{t}}$ & $135.00 \pm 10.00^{\mathrm{t}}$ & $130.00 \pm 2.89^{\mathrm{s}}$ & $112.90 \pm 9.94^{\mathrm{t}}$ \\
\hline 2 & $144.30 \pm 3.45^{\mathrm{s}}$ & $153.60 \pm 3.77^{\mathrm{t}}$ & $140.00 \pm 2.89^{\mathrm{t}}$ & $123.30 \pm 10.80^{\mathrm{t}}$ \\
\hline 3 & $159.30 \pm 5.50^{\mathrm{t}}$ & $165.00 \pm 4.08^{\mathrm{t}}$ & $150.00 \pm 2.89^{\mathrm{t}}$ & $133.30 \pm 10.80^{\mathrm{t}}$ \\
\hline 4 & $169.30 \pm 3.45^{\mathrm{t}}$ & $173.60 \pm 2.44^{\mathrm{t}}$ & $160.00 \pm 2.89^{\mathrm{t}}$ & $147.50 \pm 8.80^{\mathrm{t}}$ \\
\hline 5 & $174.00 \pm 1.89^{\mathrm{t}}$ & $178.60 \pm 2.44^{\mathrm{t}}$ & $165.70 \pm 4.50^{\mathrm{t}}$ & $152.50 \pm 8.80^{\mathrm{t}}$ \\
\hline $\mathrm{n} 6$ & $182.90 \pm 2.67^{\mathrm{t}}$ & $188.60 \pm 3.78^{\mathrm{t}}$ & $170.70 \pm 7.32^{\mathrm{t}}$ & $157.50 \pm 8.80^{\mathrm{t}}$ \\
\hline 7 & $188.60 \pm 2.44^{\mathrm{t}}$ & $193.60 \pm 2.44^{\mathrm{t}}$ & $171.40 \pm 17.25^{\mathrm{t}}$ & $159.30 \pm 18.82^{\mathrm{t}}$ \\
\hline 8 & $190.00 \pm 2.45^{\mathrm{t}}$ & $195.00 \pm 2.47^{\mathrm{t}}$ & $175.30 \pm 6.24^{\mathrm{t}}$ & $165.40 \pm 7.34^{\mathrm{t}}$ \\
\hline
\end{tabular}

Means \pm SD for seven rats per group; Means in the same row having different letters are significantly different from each other at $95 \%$ confidence level (t-test).

Table 6. Weight of rat organs (g) from the control and experimental groups

\begin{tabular}{|l|l|l|}
\hline Tissue & Control group & Experimental group \\
\hline Liver & $6.84 \pm 1.08^{\mathrm{t}}$ & $6.17 \pm 1.15^{\mathrm{t}}$ \\
\hline Kidney & $0.91 \pm 0.26^{\mathrm{t}}$ & $1.03 \pm 0.21^{\mathrm{t}}$ \\
\hline Heart & $0.54 \pm 0.08^{\mathrm{t}}$ & $0.50 \pm 0.06^{\mathrm{t}}$ \\
\hline Spleen & $0.69 \pm 0.13^{\mathrm{t}}$ & $0.87 \pm 0.16^{\mathrm{t}}$ \\
\hline
\end{tabular}

Means \pm SD for seven rats per group. Group A: control, Group B: experimental.

There are no significant differences at 5\% level (t-test). 
Table 7. Results of blood haematology and biochemistry analyses

\begin{tabular}{|c|c|c|}
\hline Parameters & Control group & Experimental group \\
\hline \multicolumn{3}{|l|}{ Haematology } \\
\hline PCV (\%) & $43 \pm 1.73^{t}$ & $42.20 \pm 1.72^{t}$ \\
\hline $\mathrm{Hb}(\mathrm{mg} / \mathrm{dl})$ & $13.89 \pm 0.77^{t}$ & $13.45 \pm 0.74^{t}$ \\
\hline $\operatorname{RBC}\left(10^{6} / \mu \mathrm{l}\right)$ & $7.14 \pm 0.33^{\mathrm{t}}$ & $7.02 \pm 0.38^{t}$ \\
\hline MCV (fl) & $60.2 \pm 1.35^{t}$ & $57.00 \pm 2.00^{t}$ \\
\hline MCHC (\%) & $32.27 \pm 0.60^{t}$ & $31.88 \pm 0.64^{t}$ \\
\hline WBC $\left(10^{3} / \mu \mathrm{l}\right)$ & $8.26 \pm 1597.58^{\mathrm{t}}$ & $8.76 \pm 3346.40^{t}$ \\
\hline Platelets $\left(10^{5}\right)$ & $1.67 \pm 41400.48^{\mathrm{t}}$ & $1.89 \pm 71435.05^{\mathrm{t}}$ \\
\hline Neutrophyl (\%) & $27.71 \pm 14.95^{\mathrm{t}}$ & $21.00 \pm 6.90^{t}$ \\
\hline Monocyte (\%) & $1.57 \pm 0.98^{\mathrm{t}}$ & $1.67 \pm 0.52^{t}$ \\
\hline Eosinophil (\%) & $5.00 \pm 4.47^{\mathrm{t}}$ & $3.17 \pm 2.32^{\mathrm{t}}$ \\
\hline Lymphocyte (\%) & $65.71 \pm 15.88^{t}$ & $74.50 \pm 6.47^{t}$ \\
\hline \multicolumn{3}{|l|}{ Biochemistry } \\
\hline Total protein & $6.91 \pm 0.31^{\mathrm{t}}$ & $6.67 \pm 0.46^{\mathrm{t}}$ \\
\hline Albumin & $3.13 \pm 0.48^{\mathrm{t}}$ & $2.93 \pm 0.46^{\mathrm{t}}$ \\
\hline Globulin & $3.79 \pm 0.24^{t}$ & $3.73 \pm 0.48^{t}$ \\
\hline A.G Ratio & $0.81 \pm 0.19^{t}$ & $0.77 \pm 0.21^{\mathrm{t}}$ \\
\hline AST & $25.57 \pm 14.55^{t}$ & $34.83 \pm 4.36^{t}$ \\
\hline ALT & $15.14 \pm 6.41^{t}$ & $20.33 \pm 9.87^{t}$ \\
\hline BUN & $13.14 \pm 1.07^{\mathrm{t}}$ & $12.33 \pm 1.97^{t}$ \\
\hline Creatinine & $0.50 \pm 0.28^{t}$ & $0.52 \pm 0.44^{\mathrm{t}}$ \\
\hline
\end{tabular}

Means \pm SD for seven rats per group. Group A: control, Group B: experimental. AST- Aspartate aminotransferases, ALT- Alanine aminotransferases, A/G Ratio- albumin globulin ratio. There are no significant differences at 5\% level (t-test). Means in the same row having the same letters are not significantly different.

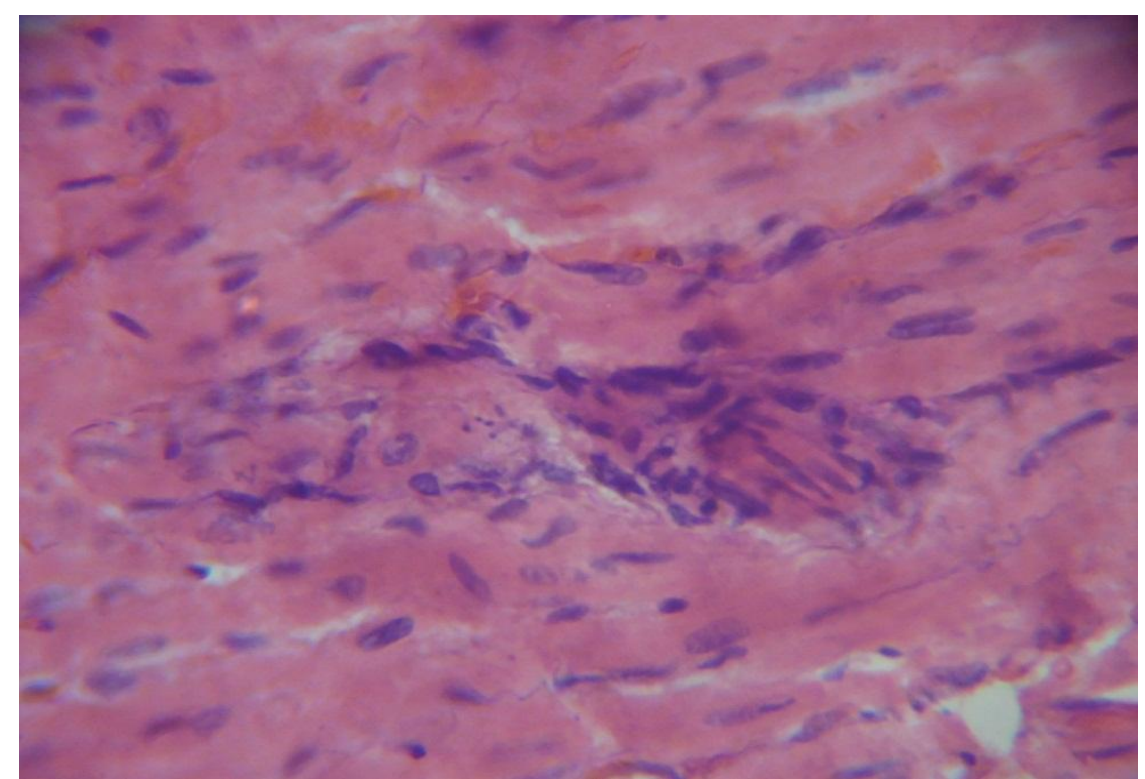

Fig 1. Photomicrograph of the heart of a test rat showing multiple foci of increased cellularity of intermyocardial tissue and moderately congested coronary vessels (x550). 